\section{Dyp hjernestimulering er effektivt}

\author{
Dyp hjernestimulering forbedrer \\ motorisk funksjon og livskvalitet ved \\ Parkinsons sykdom mer effektivt enn \\ optimal medikamentell behandling.
}

255 pasienter med avansert Parkinsons sykdom ble i en amerikansk studie randomisert til å motta enten optimal medikamentell behandling eller bilateral dyp hjernestimulering $\mathrm{i}$ enten globus pallidus eller nucleus subthalamicus (1).

Etter seks måneder anga pasientene med dyp hjernestimulering å ha tilfredsstillende motorisk funksjon 4,5 timer mer hver dag enn pasientene i medikamentgruppen. Andelen alvorlige uønskede hendelser var imidlertid høyere i stimuleringsgruppen, med 49 hendelser hos de 122 opererte pasientene, sammenliknet med 15 slike hendelser hos de 134 pasientene i medikamentgruppen. Stimuleringsgruppen hadde også små, men signifikante utfall i enkelte kognitive funksjoner, og var også noe mer utsatt for fall enn medikamentgruppen.

- Resultatene bekrefter tidligere funn fra tysk studie. Det er nå godt dokumentert at både motorisk funksjon og livskvalitet ved langtkommet, komplisert Parkinsons sykdom blir signifikant bedre ved dyp

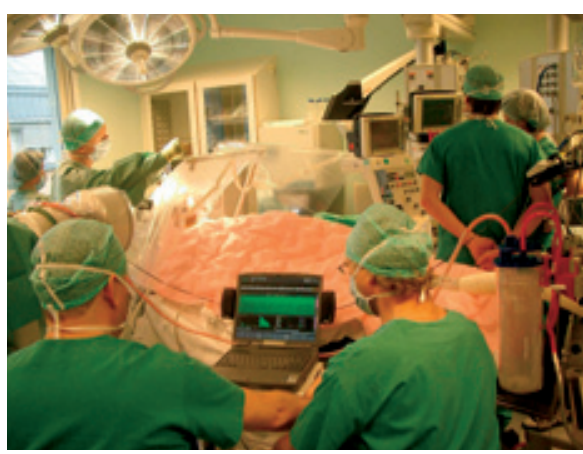

Implantasjon av elektroder for dyp hjernestimulering hos en parkinsonpasient. Foto Rikshospitalet

hjernestimulering enn ved optimal medikamentell behandling. Dette er også tilfellet hos noe eldre pasienter, idet en firedel av de opererte var over 70 år, sier avdelingssjef Espen Dietrichs ved Nevrologisk avdeling, Rikshospitalet.

\section{Are Brean}

are.brean@siv.no

Tidsskriftet

\section{Litteratur}

Weaver FM, Follett K, Stern M et al. Bilateral deep brain stimulation vs best medical therapy for patients with advanced Parkinson disease A randomized controlled trial. JAMA 2009: 301: 63-73.

\title{
Brystkreft og akupunktur
}

\section{Akupunktur reduserer forekomst av hetetokter og bedrer livskvaliteten hos kvinner som er operert for bryst- kreft og som behandles med tamoksi- fen. Det viser en norsk studie.}

Studien omfattet 59 brystkreftopererte kvinner ved Smerteklinikken, Sykehuset i Vestfold i perioden 2002-06 (1). Kvinnene ble medisinert med østrogenantagonisten tamoksifen. De ble randomisert i to grupper: ti uker med tradisjonell kinesisk akupunktur eller med overflatiske nålestikk (sham). Antall hetetokter ble notert i fire uker før påbegynt behandling, under behandlingsperioden og i 12 uker etter endt behandling. Den validerte livskvalitetsindeksen Kupperman Index ble utfylt ved behandlingsstart, ved behandlingsslutt og 12 uker senere.

Under behandlingsperioden ble antall hetetokter redusert med $50 \%$ på dagtid og $60 \%$ om natten. Det var en ytterligere $30 \%$ reduksjon både dag og natt i løpet av de neste 12 ukene i akupunkturgruppen. I shamgruppen observerte vi en signifikant $25 \%$ reduksjon i antall hetetokter om natten, men effekten ble reversert de neste 12 ukene. Det var ingen reduksjon i hetetoker om dagen. Kupperman Index ble redusert med $44 \%$ fra behandlingsstart til -slutt, og opprettholdt under oppfølgingsperioden i akupunkturgruppen. Ingen signifikante forandringer ble observert $\mathrm{i}$ shamgruppen.

Studien viser at akupunktur hadde effekt både på reduksjon av antall hetetokter og på bedring av livskvalitet $\mathrm{i}$ tre måneder etter endt behandling. I nye studier bør det undersøkes hvor lenge denne effekten varer, om pasienter oppsøker akupunktur på nytt eller velger andre typer behandling. Resultatene indikerer at akupunktur, som er rimelig, og ikke har noen kliniske relevante bivirkninger, burde anbefales til brystkreftopererte kvinner som plages av hetetokter.

\section{Jill Angela Hervik \\ jill.hervik@siv.no}

Sykehuset i Vestfold

\footnotetext{
Litteratur

1. Hervik J Miåland O. Acupuncture for the treat-

ment of hot flashes in breast cancer patients, a randomized, controlled trial. Breast Cancer Res Treat 2008; doi 10.1007/s10549-008-0210-3.
}

\section{Lik genetikk ved bipolar lidelse og schizofreni}

En analyse av ni millioner mennesker i Sverige over en 30-årsperiode har vist at bipolar lidelse og schizofreni har samme genetiske årsaker (Lancet 2009; 373:

234-9).

Studien omfattet 36000 nære slektninger av personer med schizofreni og 40000 nære slektninger av personer med bipolar lidelse. Begge grupper hadde økt risiko for begge disse lidelsene. Biologiske søsken hadde ni ganger større sannsynlighet for å ha schizofreni og åtte ganger større sannsynlighet for bipolar lidelse.

Halvsøsken med samme mor hadde en 3,6 ganger høyere sannsynlighet for schizofreni og 4,5 ganger større sannsynlighet for bipolar lidelse. Halvsøsken med samme far hadde en lavere risiko, med 2,7 ganger større sannsynlighet for schizofreni og 2,4 for bipolar lidelse.

\section{Intensiv insulinterapi for alvorlig syke barn}

Alvorlig syke barn utvikler ofte hypoglykemi, som er assosiert med dødelighet og infeksjoner. Intensiv insulinbehandling reduserer blodsukkerverdier til normale nivåer hos disse barna og reduserer mortalitet og infeksjonsrater. Det er konklusjonen av en prospektiv, randomisert studie i The Lancet $(2009 ; 373$ : 547-56).

Studien omfattet 700 alvorlig syke barn 317 under ett år og 383 barn 1-16 år. Barna var randomisert til å få enten intensiv insulinbehandling eller til kun å få behandling hvis blodsukkernivået ble kritisk høyt.

Gjennomsnittlig blodsukkernivå var lavere $\mathrm{i}$ intensivgruppen enn i standardgruppen. Flere pasienter i intensivgruppen utviklet hypoglykemi, men mortaliteten var lavere i intensivgruppen (3\%) enn i standardgruppen $(6 \%)$.

\section{Vold øker risiko for spontanabort} En studie av mer enn 2500 gravide kvinner i Afrika viste at de som opplever vold og misbruk fra partnere, har $50 \%$ øt risiko for spontanabort (Lancet 2009; 373: 318-24). Analysene var basert på en helseundersøkelse i Kamerun. Flere spontanaborter var assosiert med alle former for misbruk fra partnere, men følelsesmessig misbruk var sterkest assosiert med spontanabort.

Resultatene støtter at man i Afrika bør ha prenatal kontroll med henblikk på misbruk, der man har den høyeste raten av spontanabort i verden, ifølge forfatterne. 